\title{
KONSOLIDASI GERAKAN ANTI KORUPSI BERBASIS AKADEMISI MELALUI JURNAL INTEGRITAS DAN ACS 2018
}

\author{
Rustono Farady Marta \\ Magister IImu Komunikasi, Program Pascasarjana Universitas Bunda Mulia
}

Diterima 19 Februari 2019 / Disetujui 29 Maret 2019

\begin{abstract}
Corruption is the most latent crime, because it is pattern tends to be collective and is massive. Now the complexity and level has reached a worrying stage, so it needs the attention of various parties to deal with it. In addition to the Corruption Eradication Commission (KPK), of course the participation of interdisciplinary academician needs to contribute quality thinking to provide solutions to one of the major problems in Indonesia. Therefore, the KPK took the initiative to organize the dissemination of selected research results in the Jurnal Integritas in a scientific seminar while supporting the implementation of The 3rd Anti-Corruption Summit or abbreviated as ACS 2018 in Makassar. This is intended as a strategic step in consolidating the anti-corruption movement based on academician.
\end{abstract}

Keywords: Academician, ACS 2018, Corruption Eradication, Jurnal Integritas

\begin{abstract}
ABSTRAK
Tindak pidana korupsi merupakan kejahatan yang paling laten, dikarenakan polanya cenderung kolektif dan sifatnya masif. Kini kompleksitas serta tingkatannya telah mencapai tahap yang memprihatinkan, maka butuh perhatian berbagai pihak dalam menanggulanginya. Selain Komisi Pemberantasan Korupsi (KPK), tentu saja peran serta kalangan akademisi lintas disiplin ilmu perlu memberi sumbangsih pemikiran yang berkualitas guna mengatasi salah satu permasalahan besar Bangsa Indonesia ini. Oleh karena itu, KPK berinisiatif menyelenggarakan diseminasi hasil penelitian terpilih di Jurnal Integritas dalam suatu seminar ilmiah sembari mendukung pelaksanaan The $3^{\text {rd }}$ Anti-Corruption Summit atau yang disingkat ACS 2018 di Makassar. Hal ini dimaksudkan sebagai langkah strategis dalam melakukan konsolidasi gerakan anti korupsi berbasis akademisi.
\end{abstract}

Kata Kunci: ACS 2018, Akademisi, Jurnal Integritas, Pemberantasan Korupsi

*Korespondensi Penulis:

e-mail: rmarta@bundamulia.ac.id

\section{PENDAHULUAN}

Dalam rangka menyemaikan bersama semangat anti korupsi kepada seluruh warga Indonesia di Tanah Air, maka Komisi Pemberantasan Korupsi (KPK) sebagai lembaga independen nasional yang diberi kewenangan untuk menangani hal tersebut merasa terpanggil untuk menyelenggarakan
Anti-Corruption Summit (ACS). Kegiatan tahunan ini telah diadakan ketiga kalinya, sehingga diberi label The 3rd Anti-Corruption Summit 2018 dengan tema "Konsolidasi Gerakan Antikorupsi Perguruan Tinggi dan Masyarakat Sipil”.

Selain menyediakan pengetahuan antikorupsi dari segi kuantitas maupun kualitas KPK berupaya membangun 
kemajuan ilmu pengetahuan, bahkan memberikan solusi pemberantasan korupsi di Indonesia. Selanjutnya, KPK juga berupaya memotivasi para akademisi, peneliti, pegiat antikorupsi dan masyarakat luas untuk melakukan penelitian ilmiah secara spesifik pada isu korupsi dan antikorupsi.

\section{METODE PENELITIAN}

Pelaksanaan pengabdian masyarakat ini telah dilakukan dengan cara penyampaian materi hasil penelitian sebagaimana ditempuh berdasarkan tiga tahapan, antara lain sebagai berikut: (1) Seleksi tahap pertama Kompetisi Penelitian Jurnal Antikorupsi Integritas kerjasama KPK dan Universitas Paramadina, (2) Seleksi tahap kedua Presentasi Temuan Hasil Penelitian pilihan Redaktur dan/atau Mitra Bestari Jurnal Antikorupsi Integritas KPK.

Tabel.1 Pelaksanaan Seleksi Kegiatan

\begin{tabular}{|l|l|l|}
\hline No. & Keterangan & Rincian Keterangan \\
\hline \multicolumn{2}{|l|}{ Seleksi Tahap Pertama } \\
\hline 1 & $\begin{array}{l}\text { Tempat } \\
\text { pelaksanaan }\end{array}$ & $\begin{array}{l}\text { Gedung KPK Jln. HR. Rasuna } \\
\text { Said Kav.C1, Jakarta (Gedung } \\
\text { KPK lama) }\end{array}$ \\
\hline 2 & Hari/ Tanggal & Selasa, 21 November 2017 \\
\hline 3 & Waktu & pk. 14.00 - 14.45 WIB \\
\hline Seleksi Tahap Kedua \\
\hline 4 & $\begin{array}{l}\text { Tempat } \\
\text { pelaksanaan }\end{array}$ & $\begin{array}{l}\text { Gedung KPK Jln. Kuningan } \\
\text { Persada Kav.4, Jakarta } \\
\text { (Gedung KPK baru) }\end{array}$ \\
\hline 5 & Hari/ Tanggal & Selasa, 16 April 2018 \\
\hline 6 & Waktu & pk. 09.00 - selesai \\
\hline
\end{tabular}

Sumber: Olahan Peneliti

Pada tahapan seleksi perdana pihak penyelenggara telah mengumumkan 15 proposal yang lolos seleksi melalui laman https://www.paramadina.ac.id/home/homepag e-news/ankor-tahap-1, mereka yang terpilih berhak melakukan presentasi di hadapan pakar kajian anti korupsi dari berbagai disiplin ilmu. Selanjutnya terpilih sepuluh nama dan judul riset pilihan proposal terbaik.

Tabel.2 Riset Pilihan Jurnal Integritas KPK

\begin{tabular}{|c|c|}
\hline \multicolumn{2}{|r|}{ Asal Institusi } \\
\hline $\begin{array}{l}\text { Dumilah } \\
\text { Ayuningtyas, Fitria } \\
\text { Aryani Susanti, Siti } \\
\text { Khodijah Parinduri }\end{array}$ & $\begin{array}{l}\text { Integritas Kepemimpinan Anti } \\
\text { Korupsi di Sektor Kesehatan }\end{array}$ \\
\hline \multicolumn{2}{|c|}{ Universitas Indonesia } \\
\hline $\begin{array}{lr}\text { Febyan } & \text { Dimas } \\
\text { Pramanta, } & \text { Uut } \\
\text { Uswatun } & \text { Hasanah, } \\
\text { Mohammad } & \text { Rizky } \\
\text { Kurniawan } & \end{array}$ & $\begin{array}{l}\text { Pengembangan Buku Cerita } \\
\text { Interaktif Antikorupsi Berbasis } \\
\text { Teknologi Augmented Reality }\end{array}$ \\
\hline \multicolumn{2}{|c|}{$\begin{array}{c}\text { Politeknik STMI Jakarta, Telkom University \& } \\
\text { Universitas Negeri Malang } \\
\end{array}$} \\
\hline $\begin{array}{lr}\text { Rustono } & \text { Farady } \\
\text { Marta, Margaretha } \\
\text { Chaterine } & \text { Sarah } \\
\text { Harun, } & \text { Ian } \\
\text { Hendrawan } & \\
\end{array}$ & $\begin{array}{l}\text { Meretas Integritas Komunikasi } \\
\text { melalui Dunia Maya: Studi } \\
\text { Retorika Digital Menteri LHK } \\
\text { Periode 2014-2019) }\end{array}$ \\
\hline \multicolumn{2}{|c|}{ Universitas Bunda Mulia } \\
\hline $\begin{array}{lr}\text { Fathur } & \text { Rahman, } \\
\text { Achmad } & \text { Baidhowi, } \\
\text { Ruth } & \text { Agnesia } \\
\text { Sembiring } & \end{array}$ & $\begin{array}{l}\text { Pola Jaringan Korupsi di Tingkat } \\
\text { Pemerintah Desa (Studi Kasus } \\
\text { Korupsi Desa Tahun 2014-2015, } \\
\text { Desa Semare Kecamatan Kraton } \\
\text { Kabupaten Pasuruan) }\end{array}$ \\
\hline \multicolumn{2}{|c|}{ Universitas Brawijaya, Malang } \\
\hline $\begin{array}{l}\text { Mutia Rizal, Ilham } \\
\text { Nurhidayat }\end{array}$ & $\begin{array}{l}\text { Birokrat } \\
\text { Mempertahankan Integritas di } \\
\text { Tengah Budaya Paternalistik } \\
\text { (Studi Kasus di Pemerintah Kota } \\
\text { Tegal) }\end{array}$ \\
\hline \multicolumn{2}{|c|}{ Pergerakan Birokrat Menulis (birokratmenulis.org) } \\
\hline $\begin{array}{l}\text { Hazhira Qudsyi, } \\
\text { Nyda } \quad \text { Afsari, } \\
\text { Achmad Sholeh }\end{array}$ & \begin{tabular}{lll} 
Upaya untuk & \multicolumn{2}{c}{ Mengurangi } \\
Ketidakjujuran & Akademik pada \\
Mahasiswa melalui & Peer- \\
Education & &
\end{tabular} \\
\hline \multicolumn{2}{|c|}{ Universitas Islam Indonesia, Yogyakarta } \\
\hline $\begin{array}{l}\text { Sukadari, Mahilda } \\
\text { Dea Komalasari, } \\
\text { Ahmad Mabruri } \\
\text { Wihaskoro }\end{array}$ & $\begin{array}{l}\text { Pengembangan Buku "Wayang } \\
\text { Pandhawa" Bervisi Antikorupsi } \\
\text { untuk Menanamkan Nilai } \\
\text { Kejujuran Siswa Sekolah Dasar }\end{array}$ \\
\hline \multicolumn{2}{|c|}{ Universitas PGRI Yogyakarta \& STPI Bina Insan Mulia } \\
\hline $\begin{array}{l}\text { M. Rabi'e, Siti } \\
\text { Nurhidayati }\end{array}$ & $\begin{array}{lr}\text { Pengembangan } & \text { Model } \\
\text { Pembangunan } & \text { Budaya } \\
\text { Antikorupsi Berbasis Keluarga } \\
\text { di Kelurahan Prenggan, Kota } \\
\text { Yogyakarta }\end{array}$ \\
\hline \multicolumn{2}{|c|}{ Universitas Negeri Yogyakarta } \\
\hline $\begin{array}{l}\text { Zuardin, Wa Ode } \\
\text { Heni Satriani }\end{array}$ & $\begin{array}{lr}\text { Menyoal Alasan } & \text { Sakit dalam } \\
\text { Mengajukan } & \text { Penundaan } \\
\text { Penahanan } & \text { ParaTersangka } \\
\text { Tindak Pidana Korupsi }\end{array}$ \\
\hline UIN Sunan Ampel S & $\begin{array}{l}\text { rabaya \& Universitas Patria Artha } \\
\text { Makassar }\end{array}$ \\
\hline $\begin{array}{l}\text { Labib Muttaqin, } \\
\text { Mihammad } \\
\text { Susanto }\end{array}$ & $\begin{array}{l}\text { Mengkaji Serangan } \\
\text { Koruptor terhadap KPK dan } \\
\text { Strategi Menghadapinya }\end{array}$ \\
\hline Universit & adjah Mada, Yogyakarta \\
\hline
\end{tabular}

\begin{tabular}{|l|l|}
\hline Nama & Judul \\
\hline
\end{tabular}


Sumber:

https://www.paramadina.ac.id/home/homepagenews/10-proposal-terbaik-pemenang-kompetisiproposal-penelitian-antikorupsi-jurnal-integritas-kpk, https://jurnal.kpk.go.id/index.php/integritas/Pengumum an_Kompetisi_Proposal, dan

https://jurnal.kpk.go.id/index.php/integritas/issue/view/

Setelah pengumuman tersosialisasi melalui daring, seiring dengan hal tersebut muncul Surat Keputusan Pejabat Pembuat Komitmen Biro Hubungan Masyarakat Komisi Pemberantasan Korupsi (KPK) No.04 Tahun 2018 tentang Penetapan Peneliti dan Biaya Penelitian Pemenang Kompetisi Penelitian Jurnal Integritas Volume 04 Nomor 01 Tahun 2018. Melalui nomenklatur yang ditandatangani oleh Elis Nurhayati pada tanggal 04 Januari 2018 tersebut, maka para peneliti yang namanya tercantum diminta segera turun ke lapangan untuk segera meraih data-data yang diperlukan dalam penyelesaian laporan penelitiannya.

Berdasarkan presentasi sepuluh riset terpilih Jurnal Integritas KPK yang diminta melakukan presentasi hasil penelitian (simak Tabel.1), kemudian artikel publikasi risetnya diunggah melalui Open Journal System (OJS) pada tanggal 04 hingga 25 Mei 2018. Adapun artikel-artikel yang telah terpublikasi dalam Jurnal Integritas Bulan Juni 2018 tersebut, kemudian diseleksi kembali sebanyak empat artikel terpilih diberi kesempatan dilibatkan dalam kegiatan diseminasi ilmiah bertajuk: Seminar Jurnal Integritas. Penyelenggaraan kegiatan ini sekaligus menjadi pre-event rangkaian The 3rd Anti Corruption Summit 2018 (ACS).

\section{HASIL DAN PEMBAHASAN}

Kegiatan ACS kali ini dibagi menjadi dua kegiatan utama, yaitu: Seminar Jurnal Integritas pada Hari Senin, 22 Oktober 2018 secara serentak di empat kampus sekaligus, ditutup dengan kegiatan inti ACS (informasi selengkapnya simak Tabel.3).

KPK bekerjasama dengan Pusat Kajian Anti Korupsi Fakultas Hukum Universitas Hasanuddin (PANKAS FH UNHAS) melibatkan 19 instansi serta lembaga independen untuk terlibat dalam
ACS 2018 ini. Persiapan kegiatan ACS ini bahkan telah dibicarakan jauh-jauh hari, ketika Hari Kamis, 13 September 2018 Febri Diansyah selaku Juru Bicara KPK mengundang Mahfud MD guna berdiskusi dengan pimpinan lembaga antirasuah terkait kegiatan tersebut.

(Sumber: https://www.jawapos.com/nasional/hukumkriminal/13/09/2018/sambangi-kpk-mahfud-md-

diskusi-soal-anti-corruption-summit-2018).

Tabel.3 Pelaksanaan Kegiatan

\begin{tabular}{|c|c|c|}
\hline No. & Keterangan & Rincian Keterangan \\
\hline \multicolumn{3}{|c|}{ Kegiatan Seminar Jurnal Integritas } \\
\hline 1 & $\begin{array}{l}\text { Tempat } \\
\text { pelaksanaan }\end{array}$ & $\begin{array}{l}\text { Aula Hidjaz, Fakultas Hukum } \\
\text { Universitas Muslim Indonesia } \\
\text { (UMI) Jln. Urip Sumoharjo } \\
\text { KM.5, Panaikang } \\
\text { Panekkukang, Makassar - } \\
\text { Sulawesi Selatan }\end{array}$ \\
\hline 2 & \multicolumn{2}{|c|}{$\begin{array}{l}\text { Selain di Kampus UMI secara serentak juga } \\
\text { diselenggarakan acara serupa di Universitas } \\
\text { Hassanudin (UNHAS), Universitas Bosowa } \\
\text { (UNIBOS), dan Universitas Patria Artha (UPA) }\end{array}$} \\
\hline 3 & Hari/ Tanggal & Senin, 22 Oktober 2018 \\
\hline 4 & Waktu & pk. $12.00-16.00 \mathrm{WIB}$ \\
\hline \multicolumn{3}{|c|}{ Kegiatan The 3rd Anti Corruption Summit 2018} \\
\hline 5 & $\begin{array}{l}\text { Tempat } \\
\text { pelaksanaan }\end{array}$ & $\begin{array}{l}\text { Four Points Hotel Makassar } \\
\text { Jln. Andi Djemma No.130, } \\
\text { Banta-Bantaeng, Rappocini, } \\
\text { Makassar - Sulawesi Selatan }\end{array}$ \\
\hline 6 & Hari/ Tanggal & $\begin{array}{l}\text { Selasa-Rabu, 23-24 Oktober } \\
2018\end{array}$ \\
\hline 7 & Waktu & pk. $07.45-18.00 \mathrm{WIB}$ \\
\hline
\end{tabular}

Sumber: https://www.cakrawalaide.com/gelar-seminarintegritas-kpk-sosialisasi-jurnal-ilmiah-berkala/

Merujuk pada tema yang diusung tahun ini "Satu Pikir, Satu Aksi, Lawan Korupsi", sehingga KPK turut mengundang berbagai pihak seperti mahasiswa, dosen, peneliti, penggiat antikorupsi dan masyarakat untuk berpartisipasi. Keterlibatan akademisi menjadi sangat vital, mengingat KPK memiliki jurnal ilmiah dengan nama Jurnal Integritas. Terbit sejak 2015, Jurnal Integritas (p-ISSN: 2477-118X; e-ISSN: 2615-7977) merupakan jurnal yang menyebarluaskan hasil penelitian atau kajian konseptual tentang korupsi dan subyek yang berelasi dengan korupsi.

Jurnal Antikorupsi Integritas terbit dua nomor dalam setahun ditujukan untuk kalangan pakar, akademisi, peneliti, praktisi, penyelenggara negara, pegiat antikorupsi, dan masyarakat pada umumnya. Berdasarkan 
proses seleksi yang telah diungkapkan penulis pada bagian metode penelitian tadi, maka terdapat empat nama yang diundang untuk terlibat dalam kegiatan diseminasi penelitian, antara lain sebagai berikut:

Tabel.3 Pelaksana Kegiatan

\begin{tabular}{|c|l|l|}
\hline \multirow{2}{*}{ No. } & Nama Lengkap & Peranan \\
\cline { 2 - 3 } & Asal Institusi & Pemateri 1 \\
\hline \multirow{2}{*}{1} & Fathur Rahman & Pemateri 2 \\
\cline { 2 - 3 } & Universitas Brawijaya, Malang \\
\hline \multirow{2}{*}{2} & Labib Muttaqin & Pemateri 3 \\
\cline { 2 - 3 } & Universitas Gadjah Mada, Yogyakarta \\
\hline \multirow{2}{*}{3} & Mutia Rizal & Pemateri 4 \\
\cline { 2 - 3 } & Pergerakan Birokrat Menulis \\
\hline \multirow{2}{*}{4} & Rustono Farady Marta \\
\cline { 2 - 3 } & Universitas Bunda Mulia \\
\hline \multirow{2}{*}{5} & Ningrum Natasya Sirait & Pembahas \\
\cline { 2 - 3 } & Universitas Sumatera Utara \\
\hline \multirow{2}{*}{6} & \multicolumn{2}{|c}{ La Ode Husen } \\
\cline { 2 - 3 } & Universitas Muslim Indonesia, Makassar \\
\hline \multirow{2}{*}{7} & \multicolumn{2}{|c|}{ Laode Muhammad Syarif } \\
\cline { 2 - 3 } & Komisi Pemberantasan Korupsi RI \\
\hline
\end{tabular}

Sumber: http://upeks.fajar.co.id/2018/10/23/seminarjurnal-integritas-kpk-di-fakultas-hukum-umi-upayaperkuat-peran-kpk/ dan Surat Undangan KPK RI No.UND/780.2/HM/01/04/56/10/2018

Kasus korupsi kolektif yang diungkap Rahman, dkk (2018:29-56) menunjukkan suatu interaksi sosial yang terbentuk dalam jaringan sosial yang intensif. Temuan riset ini terkait penyalahgunaan Dana Desa (DD) dan Alokasi Dana Desa (ADD) di Pemerintah Desa Klebun Semar Paravan Jawa Timur pada tahun 2014-2015. Aktor-aktor utama yang disorot peneliti memiliki hubungan simetris yang ditunjukkan melalui hubungan keluarga, terhubung pula oleh profesi yang sama dari jaringan keagamaan (guru madrasah) serta memiliki latar belakang sebagai tim sukses kepala desa. Meski dalam kasus ini sedang dalam penanganan hukum, nampak bahwa faktor kedekatan antar aktor di balik tindak korupsi menjadi hal utama yang patut dipertimbangkan penyidik dalam membongkar kasus ini.

Permasalahan korupsi pada tataran pemangku kebijakan tidak hanya terjadi di lingkup desa, kondisi anomali ditemukan oleh Mutia Rizal serta Ilham Nurhidayat (2018:171-198) pada tataran pemerintah kota. Kali ini terjadi di Kota Tegal, menanggapi peristiwa Operasi Tangkap Tangan (OTT)
KPK pada Walikota Siti Mashita Soeparno (SMS). Peristiwa unik yang dapat dicermati dari munculnya kasus tersebut adalah respon pegawai birokrat yang berada di bawah naungan beliau, bukan turut perihatin atas gugatan hukum yang mengarah pada atasannya tapi justru ASN (Aparatur Sipil Negara) tersebut bersorak gembira. Hal ini disebabkan cara perlawanan mereka yang ditempuh melalui model pengungkapan atau dikenal sebagai whristleblowing. Pergerakan ASN tersebut bukan saja merefleksikan upaya melawan kultur paternalistik yang mengakar sejak Sang Walikota tersebut berkuasa, tapi esensi yang lebih vital terletak pada nilai-nilai luhur sebagai cerminan integritas pegawai pemerintah yang sejatinya bertindak melayani masyarakat.

Konstruksi integritas sosok birokrat juga berhasil diungkapkan oleh Marta, dkk (2018:199-216). Adapun sudut pandang yang dipakai dari perspektif ilmu komunikasi diobservasi pada tataran Kementerian Lingkungan Hidup dan Kehutanan (LHK) Republik Indonesia. Riset ini lebih dititik beratkan pada integritas komunikasi yang ditunjukkan oleh Menteri yang menjabat periode 2014-2019, yaitu Siti Nurbaya Bakar (SNB). Penelusuran ditempuh melalui konten akun official media sosialnya di Twitter @SitiNurbayaLHK, kemudian disandingkan dengan lima portal berita daring dan press release versi daring yang dikelola oleh Pejabat Pengelola Informasi dan Dokumentasi Kementerian Lingkungan Hidup dan Kehutanan (PPID-KLHK). Hasil riset menunjukkan konsistensi cuitan SNB dengan konten berita daring maupun rilis PPID-KLHK. Kondisi ini setidaknya mampu membangun citra positif bagi masyarakat luas terkait integritas sosok pemimpin institusi pemerintah yang diharapkan menjadi panutan serta pembina kehidupan.

Ketika pejabat publik menunjukkan integritasnya, tidak sedikit pula pihak yang merasa tidak puas akan keberadaannya. Labib Muttaqin dan M. Edy Susanto (2018:101144) memotret adanya upaya melemahkan fungsi KPK, bahkan nampak pula usaha untuk membubarkan lembaga antirasuah ini atau yang disebut serangan balik koruptor. 
Riset ini mencoba untuk melihat pola fight back yang diluncurkan oleh para koruptor, dengan cara dipetakan bentuk dan polanya, kemudian dilihat cara kerjanya. Selanjutnya, peneliti memberi rekomendasi desain serta strategi ideal bagi KPK untuk mencegah dan melawan setiap serangan balik koruptor.

Gambar.1 Seminar Jurnal Integritas di UMI

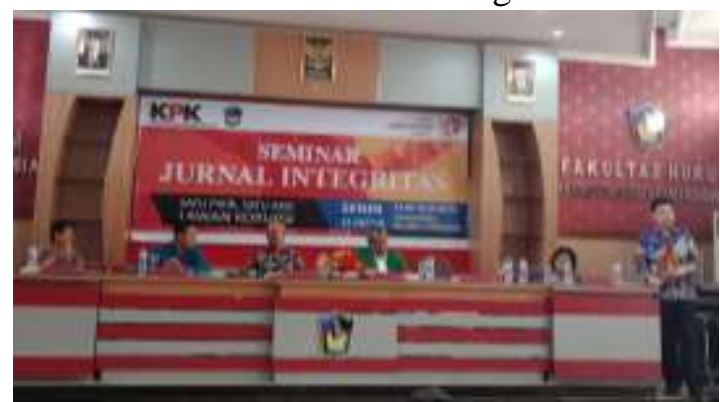

Sumber: https://www.cakrawalaide.com/gelar-seminarintegritas-kpk-sosialisasi-jurnal-ilmiah-berkala/

Keempat narasumber tersebut telah berhasil membagikan informasi perihal hasil penelitian mereka. Peserta yang dituju dari pengabdian masyarakat ini adalah 108 orang mahasiswa, dosen dan tenaga kependidikan Fakultas Ilmu Hukum. Selain itu, penyaji didampingi pula oleh Prof. Dr. Ningrum Natasya Sirait, SH, M.Li. yang selama ini dikenal sebagai Guru Besar Fakultas Hukum Universitas Sumatera Utara diminta memberi tanggapan kegiatan Seminar Jurnal Integritas. Seminar ini sepenuhnya dipandu oleh Prof. Dr. H. La Ode Husen, SH. MH. bertindak mewakili tuan rumah Universitas Muslim Indonesia sekaligus menjabat Wakil Rektor III selaku moderator, kemudian ditutup oleh Bpk. Laode Muhammad Syarif, SH., LL.M., Ph.D. selaku Wakil Ketua Komisioner KPK.

Optimalisasi pemberantasan korupsi di Indonesia menjadi perhatian utama bangsa Indonesia, agar mematangkan persiapan kita menghadapi kancah persaingan di tingkat global. Waluyo (2014:169-182) menyebutkan beberapa langkah strategis yang perlu diambil pemerintah adalah pengenaan berbagai sanksi terberat bagi pelaku tindak korupsi, baik pidana, denda, uang pengganti, pembuktian terbalik yang diakumulasikan dengan Tindak Pidana Pencucian Uang (TPPU), bersamaan dengan sanksi sosial di masyarakat sebagai efek jera. Hal ini didukung oleh riset Ridwan
(2014:385-399) bahwa pentingnya peran serta masyarakat mengambil andil yang cukup besar untuk mencegah tindak pidana korupsi.

\section{SIMPULAN}

Paparan para narasumber kegiatan Seminar Jurnal Integritas menunjukkan bahwa upaya pemberantasan korupsi dan penegakkan integritas pejabat publik sejalan dengan semangat reformasi birokrasi di Indonesia. Perilaku korupsi sendiri ditengarai oleh Suwitri (2007:23-41) sebagai perilaku yang menyimpang atau abnormal behavior, sayangnya praktek seperti ini telah mengakar sejak lama di bumi zamrud khatulistiwa sejak tingkatan birokrat paling rendah hingga yang paling tinggi. Perlu partisipasi tiap elemen masyarakat, terutamanya di kalangan akademisi dari lintas disiplin ilmu dalam memberi sumbang pikir dan tenaga yang dicurahkan terhadap kemajuan kajian anti korupsi. Oleh karena kompleksitas kejahatan tindak korupsi telah mencapai tingkat yang sangat memprihatinkan, maka Santoso, dkk (2014:173-183) menyebutkan bahwa domain pemberantasan korupsi tidak dapat berhenti hanya pada ranah hukum. Justru terletak pada kendala kultural di masyarakat, rendahnya mentalitas serta kepekaan ruang batinnya. Dalam kajian sosial politik serta kebudayaan, melihat fenomena ini sebagai penyebab utama masifnya tindak kejahatan korupsi. Kondisi ini pula yang distimuli oleh Jurnal Integritas guna mendiseminasikan sekaligus mewadahi potensi besar para akademisi dan peneliti melahirkan pemikiran dan gagasan yang mencerahkan banyak pihak terkait upaya pemberantasan korupsi.

\section{DAFTAR PUSTAKA}

Marta, Rustono Farady, Margaretha Chaterine Sarah Harun, Ian Hendrawan. 2018. Meretas Integritas Komunikasi melalui Media Maya: Studi Retorika Digital Menteri LHK Periode 20142019 dalam Jurnal Integritas Vol.4(1) Juni 2018 diakses dari https://jurnal.kpk.go.id/index.php/integrit as/article/view/155/52 
Mutaqqin, Muhammad Edy Susanto. 2018. Mengkaji Serangan Balik Koruptor terhadap KPK dan Strategi Menghadapinya dalam Jurnal Integritas Vol.4(1) Juni 2018 diakses dari

https://jurnal.kpk.go.id/index.php/integrit as/article/view/146/45

Rahman, Fathur, Achmad Baidhowi, Ruth Agnesia Sembiring. 2018. Pola Jaringan Korupsi di Tingkat Pemerintah Desa (Studi Kasus Korupsi DD dan ADD Tahun 20142015 di Jawa Timur) dalam Jurnal Integritas Vol.4(1) Juni 2018 diakses dari

https://jurnal.kpk.go.id/index.php/integrit as/article/view/198/47

Ridwan. 2014. Upaya Pencegahan Tindak Pidana Korupsi melalui Peran serta Masyarakat dalam Kanun Jurnal Ilmu Hukum No.64 Th.XVI Desember 2014 diakses dari http://www.jurnal.unsyiah.ac.id/kanun/art icle/viewFile/6037/4975

Rizal, Mutia, Ilham Nurhidayat. 2018. Birokrat Melawan: Mempertahankan Integritas di tengah Budaya Paternalistik (Studi Kasus di Pemerintah Kota Tegal) dalam Jurnal Integritas Vol.4(1) Juni 2018 diakses dari

https://jurnal.kpk.go.id/index.php/integrit as/article/view/153/51

Santoso, Listiyono, Dewi Meyriswati, Ilham Nur Alfian. 2014. Korupsi dan Mentalitas: Kendala Kultural dalam Pemberantasan Korupsi di Indonesia dalam Masyarakat, Kebudayaan, dan Politik Vol.27(4) Oktober 2014 diakses dari https://ejournal.unair.ac.id/MKP/article/view File/2483/1795

Sawitri, Sri. 2007. Pemberantasan Korupsi di Indonesia: Sebuah Upaya Reformasi Birokrasi dalam DIALOGUE: Jurnal Ilmu Administrasi Kebijakan Publik (JIAKP) Vol.4(1) Januari 2007 diakses dari https://ejournal.undip.ac.id/index.php/dial ogue/article/downloadSuppFile/179/11

Waluyo, Bambang. 2014. Optimalisasi Pemberantasan Korupsi di Indonesia dalam Jurnal Yuridis Vol.1(2)
Desember 2014 diakses dari http://library.upnvj.ac.id/pdf/artikel/Artik el_jurnal_FH/Jurnal\%20Yuridis/jy-vol1no2-des2014/169-182.pdf

\section{Sumber lainnya:}

Surat Keputusan Pejabat Pembuat Komitmen Biro Hubungan Masyarakat Komisi Pemberantasan Korupsi Nomor 04 Tahun 2018 tentang Penetapan Peneliti dan Biaya Penelitian Jurnal Integritas Volume 04 Nomor 01 Tahun 2018

Surat Undangan Komisi Pemberantasan Korupsi Republik Indonesia No.UND/780.2/HM/01/04/56/10/201 8 perihal Undangan Penyaji Seminar Jurnal Integritas

https://www.jawapos.com/nasional/hukumkriminal/13/09/2018/sambangi-kpkmahfud-md-diskusi-soal-anti-corruptionsummit-2018

https://www.paramadina.ac.id/home/homepagenews/10-proposal-terbaik-pemenangkompetisi-proposal-penelitianantikorupsi-jurnal-integritas-kpk

https://www.paramadina.ac.id/home/homepagenews/ankor-tahap-1

https://jurnal.kpk.go.id/index.php/integritas/Pengu muman_Kompetisi_Proposal

https://www.cakrawalaide.com/gelar-seminarintegritas-kpk-sosialisasi- jurnal-ilmiahberkala/

http://upeks.fajar.co.id/2018/10/23/seminar-jurnalintegritas-kpk-di-fakultas-hukum-umiupaya-perkuat-peran-kpk/ 